\title{
Srebrna gospodarka jako impuls w rozwoju przestrzennym i społecznym miasta
}

\section{Silver economy as the impulse in spatial and social development of the city}

\section{Streszczenie}

Artykuł prezentuje aspekt starzejącego się społeczeństwa oraz rozwój srebrnej gospodarki jako impuls i wyzwanie do poszukiwania nowych wartości w przestrzeni miejskiej. Proces ten odzwierciedlają przykłady pozytywnych rozwiązań w zakresie wspomaganych form zabudowy mieszkaniowej dla osób starszych, np. domy i osiedla wielopokoleniowe. Jako przykład współpracy pomiędzy środowiskiem naukowym a sektorem biznesu oraz samorządami prezentowana jest działalność Fundacji Laboratorium Architektury 60+.

Słowa kluczowe: starzejące się społeczeństwo, srebrna gospodarka, domy międzypokoleniowe, projektowanie dla osób starszych

\section{Abstract}

Article presents the aspect of ageing society and the development of silver economy as the impulse to searching of new values in the city space. This process reflects the positive examples of the housing estates for the elderly i.e. the intergenerational houses and settlements. As the example of the cooperation between the science, the business sector and the local government is the activity of Foundation Laboratory of Architecture 60+.

Keywords: ageing society, silver economy, intergenerational houses, design for the elderly 


\section{WSTĘP}

Proces starzenia się społeczeństwa wymusza szereg zmian w dotychczasowym myśleniu o jakości przestrzeni współczesnych miast. Jednym z wyzwań jest potrzeba zmian w procesie przekształceń przestrzennych, wymagającym wprowadzenia nowych wartości służących podtrzymaniu aktywności fizycznej i społecznej licznej grupy osób w wieku 65+, stworzenia warunków niezależnego zamieszkiwania oraz zapewnienia dostępu do podstawowych usług i rekreacji. Proces starzenia to także wyzwanie stymulujące rozwój nowych sektorów przedsiębiorczości, czego przykładem jest rozwój srebrnej gospodarki. W podstawowym zakresie jest ona rozumiana jako wykorzystanie potencjału nabywczego w oparciu o potrzeby konsumpcyjne, zdrowotne i bytowe seniorów ${ }^{1}$. Natomiast pełne rozumienie tej gałęzi gospodarki ujęte jest znacznie szerzej, na podstawie analizy cech tej grupy społecznej, aby wykorzystać je do zwiększenia aktywności i samodzielności seniorów oraz do rozwoju struktur związanych z seniorami ${ }^{2}$. Wówczas zainteresowanie koncentruje się także na osobach młodszych w aspekcie dostarczania im usług pozwalających na dłuższą aktywność zawodową oraz samodzielność życiową. Rozszerzenie spektrum podejmowanych działań wynika bowiem z jednego z współczesnych paradygmatów polityki senioralnej, jakim jest aktywne starzenie się w dobrym zdrowiu, utrzymanie niezależności i aktywny udział w życiu społecznym. Zakres podejmowanych działań dotyczy zatem nie tylko sektora usług zdrowotnych i opiekuńczych, ale także transportu, rozwoju form mieszkaniowych, stwarzania mechanizmów umożliwiających uczestnictwo osób starszych w życiu publicznym. Życie i aktywność seniorów ma wiele wymiarów, a jakość przestrzeni miast, w szczególności struktur mieszkaniowych, jest jednym z ważniejszych czynników wspomagających zdolności funkcjonalne osób starszych. Stwarza warunki do podejmowania różnych ról społecznych, ale także do uczestniczenia w życiu społecznym na różnych poziomach zaangażowania. Należy mieć na uwadze, że aktywna starość ma różnorodne wymiary postrzegania: indywidualny - z punktu widzenia subiektywnych odczuć, pod kątem czynników oceny jakości życia popartych założeniami naukowymi oraz w obszarze realizacji programów polityki społecznej. Wynika stąd, że poziom akceptacji aktywizacji osób starszych może być zróżnicowany wśród różnych grup wiekowych i społecznych, co wpływa na znaczenie solidarności międzypokoleniowej i kształtowanie polityki antywykluczeniowej ${ }^{3}$. Ma to między innymi konsekwencje dla kształtowania modelu zabudowy mieszkaniowej.

Specyfika ograniczeń funkcjonalnych osób starszych powoduje, że jakość budynków mieszkalnych warunkuje w znacznym stopniu ich codzienne funkcjonowanie. Poszukiwane są więc rozwiązania przestrzenne odpowiadające na zmieniającą się sprawność fizyczną i psychospołeczną osób starszych, co dotyczy zarówno rozwiązań w skali urbanistycznej (np. dostępność usług, komunikacji), jak i skali architektonicznej (np. rozwiązania komunikacji w budynku, jego wyposażenie). Ponadto dynamicznie rozwijają się produkty i innowacje w zakresie nowoczesnych systemów monitorowania i pomocy osobistej dla osób starszych. 
Pozwalają one na pomoc w nagłych przypadkach w miejscu zamieszkania i przypomnienie o codziennych czynnościach, ale także są czynnikiem zmniejszającym liczbę hospitalizacji z uwagi na możliwość monitorowania seniora. Jest to przykład wprowadzania nowych produktów będących odpowiedzią na potrzeby osób starszych jak i wspomagające dotychczasowe struktury opiekuńcze.

Równocześnie proces starzenia się społeczeństwa jest w warunkach polskich przedmiotem szczególnych działań lokalnych władz lub instytucji, gdyż coraz więcej wprowadza się rozwiązań przyjaznych seniorom. Takim przykładem jest Lublin, gdzie Społeczna Rada Seniorów rozpoczęła w 2012 roku akcję „Miejsca Przyjazne Seniorom”. Akcja ma na celu wyróżnienie oraz promowanie specjalnym certyfikatem instytucji i usług w Lublinie, które wychodzą naprzeciw oczekiwaniom osób starszych pod względem oferowanych usług, stosowanych zniżek oraz dostępności architektonicznej. Natomiast elementem stymulującym rozwój przestrzenny miasta i wprowadzającym nowe wartości byłaby niewątpliwie strategia kształtowania polityki miejskiej, która przez szeroką realizację potrzeb osób starszych, przez rozwój różnych gałęzi srebrnej gospodarki przyczynia się do zwiększenia ich aktywności i roli w życiu społecznym. Może być to czynnikiem zwiększenia konkurencyjności miast lub może stać się czynnikiem wyróżniającym, służącym podniesieniu atrakcyjności i przyjazności przestrzeni. Jest to także ruch w kierunku budowania społeczeństwa kreującego wspólnie, międzypokoleniowo społeczny charakter procesu starzenia, w kierunku społeczeństwa przyjaznego starzeniu. Dyskurs nad miastem przyjaznym seniorom narodził się w ramach programu Globalnej Sieci Miast i Gmin Przyjaznych Starzeniu, zainicjowanego przez Światową Organizację Zdrowia w 2002 r. Podstawowym aspektem jest w nim jak najdłuższa samodzielność i niezależność osób starszych, realizowana przez ${ }^{4}$ :

- promocję zdrowego stylu życia na wszystkich jego etapach,

- kształtowanie przyjaznego otoczenia z wykorzystaniem zasad projektowania uniwersalnego, zapewniającego dostępność dla osób starszych i osób z niepełno-sprawnościami,

- wspomaganie osób starszych usługami rehabilitacyjnymi,

- wykorzystanie możliwości nowoczesnych technologii dla wspomagania niezależności w miejscu zamieszkania,

- integracja opieki zdrowotnej i usług opiekuńczych,

- działania na rzecz społecznych więzi tworzących sieci wsparcia dla osób starszych.

Wymienione działania nakładają odpowiedzialność przede wszystkim na lokalne władze samorządowe, jednak muszą one angażować także społeczność lokalną, aby uzyskać efekty trwałe społecznie. Powracając do zagadnienia zwiększania aktywności i samodzielności seniorów, powstaje pytanie, jaki charakter działań w wymiarze przestrzennym powinno się podejmować, aby zapewnić starszemu pokoleniu aktywny udział w życiu społecznym? Jakie rozwiązania przestrzenne pozwalają wspomagać osoby starsze w ich zdolnościach funkcjonalnych i kompetencjach? 


\section{DOTYCHCZASOWE STRATEGIE DZIAŁAŃ NA RZECZ POPRAWY JAKOŚCI ŻYCIA OSÓB STARSZYCH - WYMIAR ŚRODOWISKA MIESZKANIOWEGO}

Poszukiwania efektywnych rozwiązań w zakresie zabudowy mieszkaniowej są jednym z priorytetowych wyzwań w obliczu postępującego starzenia się społeczeństwa. Warunki mieszkaniowe są bowiem miejscem zaspokajania większości potrzeb5 ${ }^{5}$. Poszukuje się między innymi najbardziej optymalnych rozwiązań dla osób starszych, zwłaszcza dla tych wymagających opieki. Wśród funkcjonujących form zabudowy mieszkaniowej, w której mieszkają osoby starsze, wyróżnić można6:

a) główny nurt zabudowy mieszkaniowej: zabudowa typowa, zabudowa umożliwiająca adaptację dla różnych grup użytkowników (zmienności potrzeb w cyklu życia) oraz zabudowa dostępna dla grup o różnej sprawności;

b) specjalne formy budownictwa mieszkaniowego dla osób starszych:

- mieszkania niezależne, z możliwymi systemami dozoru, dostępem do form aktywności dedykowanych seniorom, z przestrzeniami wspólnymi, z dochodzącymi opiekunami; mieszczą się w tej formie wspólnoty mieszkaniowe, osiedla dla seniorów, mieszkania w zespołach lub domach kolektywnych,

- pielęgnacyjne domy spokojnej starości zapewniające kompleksową opiekę i pomoc w podstawowych czynnościach życiowych, w tym także posiłki (assisted living),

- wielofunkcyjne zespoły urbanistyczne składające się z niezależnych mieszkań, domu opieki i ośrodka geriatrycznego (continuing care retirement communities);

c) formy mieszkaniowe z opieką instytucjonalną

- domy seniora z zapewnionymi posiłkami, indywidualną opieką personelu (residental homes),

- domy opieki z całodobowym dozorem personelu pielęgniarskiego (nursing homes),

- specjalne domy opieki dla osób starszych (np. dla osób chorych na demencję).

Pod kątem uwarunkowań społecznych optymalnym modelem zabudowy mieszkaniowej dla osób starszych jest model zróżnicowany pod kątem wieku mieszkańców, czyli odchodzący od swego rodzaju getta dla seniorów. Wyburza się lub remontuje zespoły mieszkaniowe w złym stanie technicznym i uzupełnia się strukturę miasta mieszkaniami socjalnymi dla seniorów. Nowo projektowane mieszkania powstają także jako fragment nowo powstających założeń komercyjnych. Natomiast działania w krajach europejskich, takich jak Dania, Anglia, Austria skupiają się na promocji społeczności lokalnych typu mixed communities - miksu społeczności składających się z przedstawicieli różnych grup społecznych, wiekowych i etnicznych. Podstawowym, najmniej radykalnym sposobem na uzyskanie takich niehomogenicznych zespołów mieszkaniowych jest zróżnicowanie typów mieszkań w obrębie każdego założenia, tzn. zróżnicowanie standardów mieszkań. Ale stosowane są także rozwiązania, które są wielogeneracyjnymi zespołami dla osób starszych, młodych małżeństw i rodzin z dziećmi (tzw. domy międzypokoleniowe) albo są to formy tzw. cohousingu senioralnego 
- czyli form zamieszkania, gdzie seniorzy tworzą grupy sąsiedzkie, użytkujące wspólne przestrzenie i dzielące wspólnie część codziennych obowiązków. Takim przykładem są obiekty w Londynie, w dzielnicy High Barnet czy Frauen Werk Stadt II jako eksperymentalny cohousing senioralny dedykowany starszym kobietom ${ }^{7}$. Tego typu rozwiązania pozwalają obniżać koszty społeczne opieki nad osobami starszymi, ale wymagają z pewnością uruchomienia procesu zaangażowania wspólnot sąsiedzkich.

Znakomitym przykładem osiedla wielopokoleniowego jest amerykański zespół Bridge Meadows. Jest to osiedle zaprojektowane z myślą o rodzinach z adoptowanymi dziećmi oraz o samotnych seniorach. W osiedlu realizowany jest specjalny program społeczny animowany przez fundację: seniorzy otrzymują dofinansowanie do czynszu w zamian za pomoc i pracę na rzecz społeczności: przez 7 godzin tygodniowo są zobowiązani do spędzania czasu z dziećmi na majsterkowaniu, robótkach ręcznych, lekcjach muzyki, opowiadaniu bajek, zabieraniu dzieci na spacery. Budynki mieszkalne są zlokalizowane wokół wewnętrznego wspólnie użytkowanego dziedzińca. Osiedle składa się z 9 domów dla rodzin i 27 jedno- i dwuosobowych apartamentów dla seniorów (il. 1). Skala budynków, ich wygląd ma wiele cech swojskości - w zespole utrzymana jest estetyka „dobrego sąsiedztwa”. Wewnętrzny dziedziniec jako wnętrze urbanistyczne pełni rolę przestrzeni społecznej. Integracji międzypokoleniowej sprzyjają ogródki uprawne, służące wspólnym pracom czy elementy architektury budynków, w których balkony czy tarasy z miejscami do siedzenia są zwrócone do dziedzińca jako do serca całego założenia (il. 2a, 2b). W centrum osiedla zlokalizowano dwukondygnacyjny budynek Centrum Międzygeneracyjnego z przyległym placem. Jest to przestrzeń służąca spotkaniom lub imprezom organizowanym wspólnie przez mieszkańców.

Innym przykładem realizacji tego typu społecznej zabudowy jest dom międzypokoleniowy Heslach w Stuttgarcie. Zlokalizowany jest w śródmiejskiej zabudowie, wśród łatwo dostępnych usług (il. 3a, 3b). W budynku mieszczą się 82 mieszkania dla osób starszych i niepełnosprawnych młodszych mieszkańców, a na najwyższych kondygnacjach zlokalizowane zostały mieszkania wspomagane dla wymagających stałej opieki osób starszych. Nadrzędną funkcją domu jest integracja wielopokoleniowa, animowana przez organizację pozarządową Wabe e.V., dlatego odbywają się tam spotkania, imprezy i wydarzenia kulturalne, organizowana jest opieka dla osób starszych oraz dzienna opieka nad dziećmi, spotkania klubowe i warsztaty, a także zapewnione są usługi doradcze dla seniorów i rodzin. Większość przestrzeni wspólnych stwarza warunki do spotkań. Wielofunkcyjność obiektu jest jednocześnie czynnikiem integracji z lokalną społecznością: w budynku umieszczono funkcje takie jak sklepy, świetlice, przychodnia lekarska, dom kultury, pomieszczenia klubowe itp., a także restaurację prowadzoną przez mieszkańców ${ }^{8}$.

Tego typu formy mieszkaniowe zostały ocenione w Niemczech jako czynnik stabilizujący stosunki społeczne w skali osiedla, dzielnicy czy nawet miasta. Obniża to koszty opieki społecznej nad osobami zależnymi, a także wzmacnia poczucie bezpieczeństwa, użyteczności społecznej. W wymiarze społecznym stanowi także miejsce wsparcia dla grup społecznych 
zagrożonych wykluczeniem ${ }^{9}$. Jest to więc niewątpliwie przykład podążania za szerokim zakresem potrzeb osób starszych i podtrzymania ich roli w społeczeństwie, co jako wartość przestrzenna i społeczna wzbogaca przestrzeń miejską.

Samorządy oraz prywatni inwestorzy w Polsce inicjują szereg działań przestrzennych w kierunku tworzenia specjalnych form mieszkaniowych dla seniorów. Takim przykładem jest osiedle w Stargardzie Szczecińskim. Jest to wspólne przedsięwzięcie gminy Stargard Szczeciński, stargardzkiego TBS. Pozostałymi partnerami projektu był Uniwersytet Trzeciego Wieku, Polski Związek Emerytów, Rencistów i Inwalidów oraz Stowarzyszenie „Potrzebny Dom”. Obiekt zakładał realizację osiedla dla osób w wieku 55+, które mają mieć zapewniony dostęp do pomocy w codziennych czynnościach dzięki pracy w ramach wolontariatu. Dotąd został zrealizowany pierwszy segment, natomiast docelowo zespół będzie składać się z czterech podobnych budynków. Obiekt realizuje właściwy poziom intymności w przestrzeniach prywatnych oraz stwarza przestrzenie integracji mieszkańców. Trzy segmenty mieszkalne połączone są łącznikami z funkcjami gospodarczymi i przestrzeniami wspólnymi - umieszczono w nich świetlice z aneksami kuchennymi, szatnie dla wolontariuszy, WC, a w jednym z budynków także pokój zabiegów pielęgniarskich. W każdym zespole występują mieszkania jedno- i dwupokojowe oraz komórki lokatorskie (il. 4).

Inne przykłady to projekt osiedla w Zawadzie pod Krakowem, projekt osiedla w Radkowie czy niedawno powstały projekt osiedla „Centrum 50+”, które realizowane będzie przez gliwicki ZBM II TBS. Jednak wśród nowopowstających osiedli dla seniorów w Polsce przeważa model osiedla przeznaczonego wyłącznie dla osób starszych, co jest rozwiązaniem dyskusyjnym, skupiającym na danym terenie większość mieszkańców w starszym wieku. Jednocześnie osiedla te najczęściej oferują mieszkania o wysokim standardzie, co jest wykluczeniem grupy osób słabszych ekonomicznie. Nie wprowadza to elementu typowej miejskiej różnorodności i rozwoju struktur mieszkaniowych.

W ramach prywatnego sektora usług realizowane są także obiekty opieki instytucjonalnej w formie domów seniora z całodobową opieką medyczną i monitoringiem, wyżywieniem oraz z ofertą zajęć terapeutycznych i rehabilitacyjnych. Są to jednak obiekty dostępne dla seniorów o wyższym statusie ekonomicznym np. Senior Residence na osiedlu Bażantowo w Katowicach (il. 5a, 5b) czy Dom Opieki Angel Care we Wrocławiu. Zapewniają one wyższy standard powierzchniowy przestrzeni prywatnych oraz jakość wyposażenia. W katowickim przykładzie przestrzenie pobytu podopiecznych są podzielone na tzw. grupy mieszkalne dla kilkunastu mieszkańców, każda z nich ma własne przestrzenie wspólne z aneksem kuchennym i dozór pielęgniarski. Ponadto dla mieszkańców przewidziano szereg aktywizujących zajęć terapeutycznych (np. bibliotekoterapia, dogoterapia i zajęcia z królikami, zajęcia kulinarne). Istotnym aspektem aktywizacji seniorów jest także przyległy ogród umożliwiający ruch lub bierny wypoczynek na świeżym powietrzu. 


\section{FUNDACJA LABORATORIUM ARCHITEKTURY 60+ (LAB60+) JAKO PRZYKŁAD DZIAŁAŃ NA RZECZ POPRAWY ŚRODOWISKA MIEJSKIEGO W ASPEKCIE POTRZEB OSÓB STARSZYCH}

Powstała w 2016 r. Fundacja Laboratorium Architektury LAB 60+ powołana została z inicjatywy urbanistki dr inż. arch. Agnieszki Labus. Było to efektem obserwowanego wzrostu roli rozwiązań przestrzennych dedykowanych osobom starszym w obliczu rozwoju sektora mieszkaniowego, usług zdrowotnych i opiekuńczych. Na Górnym Śląsku jest to coraz większe wyzwanie, gdyż jest to jeden z najszybciej starzejących się regionów w Polsce. Z założenia Fundacja ściśle współpracuje z Wydziałem Architektury Politechniki Śląskiej, gdyż w skład zespołu wchodzą pracownicy Wydziału. Jednak Fundacja rozwija swoje działania nie tylko w obszarze Śląska - jest partnerem kilku instytucji i organizacji, a także znajduje się na mapie innowacyjnych laboratoriów Komisji Europejskiej oraz współpracuje z instytucjami w skali europejskiej (LAB 60+ jest członkiem Konwentu Zmian Demograficznych - Convent on Demographic Changes).

Działania Fundacji są ukierunkowane tak, aby rozwijać różnorodne obszary mieszczące się w zakresie srebrnej gospodarki:

- edukacja i popularyzacja wiedzy w zakresie projektowania z uwzględnieniem potrzeb osób starszych,

- współpraca z sektorem biznesu, stwarzanie warunków do kreowania innowacyjnych rozwiązań opartych na wiedzy,

- współpraca z lokalnymi samorządami, między innymi w zakresie włączenia lokalnych społeczności (w tym osób starszych) w procesy przekształcania przestrzeni miejskich.

Społeczna odpowiedzialność interesariuszy decydujących o przestrzennych uwarunkowaniach w funkcjonowaniu osób starszych nakłada na przyszłych adeptów zawodu architekta nowe wyzwania. Dla poprawy jakości przestrzeni polskich miast istnieje zatem potrzeba uświadomienia społecznej roli zawodu architekta oraz jego wpływu na kształtowanie środowiska z myślą o użytkownikach, w tym także podniesienia podstawowych kompetencji badawczych w zakresie pozyskiwania informacji o ich potrzebach. W zakresie działań edukacyjnych popularyzowana jest wiedza dotycząca projektowania dla osób starszych i ukierunkowana na doskonalenie praktyki projektowej. Inicjowane są projekty edukacyjne z udziałem studentów architektury oraz seniorów z Uniwersytetu Trzeciego Wieku (np. projekt edukacyjny z WA PoISI dotyczący oceny, programowania i projektowania przestrzeni dla seniorów lub cykl wykładów popularyzujących wiedzę pt. „Starość Millenialsów. Miasto 2060"), co pozwala na wymianę poglądów pomiędzy pokoleniami oraz konfrontację zdobytej wiedzy z rzeczywistymi potrzebami i codziennością osób starszych. Planowany na jesień 2017 kolejny projekt edukacyjny ma dotyczyć problemów seniorów w przestrzeni publicznej i zakłada ponownie międzypokoleniowe zajęcia warsztatowe. Projekt w założeniu ma być realizowany w trójstronnym partnerstwie pomiędzy lokalnym samorządem, reprezentantem 
sektora biznesu oraz partnerami ze świata nauki. W ramach tego projektu planowany jest także otwarty konkurs architektoniczny, który ma na celu wyłonienie ciekawych propozycji mebli miejskich dla seniorów (i nie tylko), jakimi są przysiadki. Projekt ten ma na celu wywołanie szerszej debaty na temat warunków w przestrzeni publicznej miast, stwarzających seniorom możliwość uczestniczenia w życiu społecznym. Z drugiej strony - przez włączenie do projektu reprezentantów przedsiębiorców - ma być on także bodźcem do poszukiwania innowacyjnych produktów.

Jako przykład współpracy z sektorem biznesu przytoczyć można opracowaną koncepcję przestrzenną parku uzdrowiskowego w południowej Polsce. Było to opracowanie, w którym sformułowano wytyczne projektowe dla parku pod kątem integracji międzypokoleniowej, zapewnienia wypoczynku o różnym stopniu intensywności (z możliwością jej wyboru) oraz w aspekcie promocji aktywności ruchowej na świeżym powietrzu. Wyodrębniono cztery strefy funkcjonalne przedstawione na il. 6: strefa terapeutyczna (strefa A), strefa społeczna (strefa B), strefa aktywnego wypoczynku (strefa C) oraz strefa sportowa (strefa D). Wypracowanie tej koncepcji było impulsem do wypracowania przez inwestora nowego profilu usługi oferowanej osobom starszym.

W ramach działalności fundacji LAB 60+ mieści się także współpraca z instytucjami opieki medycznej i sektorem usług opiekuńczych. To niezwykle ważny wymiar potrzeb i związanych z nimi usług, decydujący o jakości życia seniorów. Jakość przestrzeni obiektów takich jak oddziały geriatryczne, dzienne domy pomocy społecznej czy domy seniora może wymiernie wpływać na jakość i efektywność opieki oraz wspomagać osobę starszą w jej codziennych czynnościach. Współpraca ze Szpitalem Geriatrycznym w Katowicach pozwoliła na wypracowanie rozwiązań projektowych na oddziale geriatrycznym wprowadzających nową jakość przestrzeni w strefie pacjenta (il. 7A, 7B). Wykorzystano wyniki dotychczasowych badań w zakresie kształtowania środowiska terapeutycznego do opracowania dwóch zakresów projektowych:

- opracowanie wytycznych projektowych do projektu informacji wizualnej i aranżacji stref społecznych (strefa wejściowa, strefy wypoczynkowe na oddziałach geriatrycznych) budynku C szpitala (proj. Studio ER Ewa Mocha we współpracy z A. Szewczenko);

- opracowanie projektu pomieszczeń terapeutycznych: pomieszczenie aktywnej rehabilitacji, sala sensoryczna oraz gabinet terapii indywidualnej (proj. I. Benek); w pomieszczeniach tych wykorzystano odmienne kody kolorystyczne i formalne, zastosowano niespotykane dotychczas w polskiej geriatrii metody terapii światłem, barwą, a także terapię z zastosowaniem tzw. Memorabiliów ${ }^{10}$.

Istotnym aspektem wymienionych projektów była współpraca interdyscyplinarna z lekarzami geriatrami lub psychologami, których doświadczenie w pracy z pacjentem geriatrycznym było istotnym czynnikiem w budowaniu założeń projektowych. Wprowadzone rozwiązania przestrzenne stały się jednocześnie ważnym elementem profilu usługi odpowiadającej na potrzeby starszych pacjentów. 


\section{PODSUMOWANIE}

Proces starzenia się społeczeństwa jest coraz częściej podejmowanym zagadnieniem w kontekście odnowy przestrzeni miejskiej. Podstawowym wymiarem poszukiwania rozwiązań przestrzennych w obliczu starzenia się społeczeństwa jest komfortu życia, ale także atrakcyjność przestrzeni miejskiej dla mieszkańców dzięki wprowadzonej różnorodności form mieszkaniowych, rekreacyjnych oraz usługowych.

Zaprezentowane działania podejmowane przez Fundację Laboratorium Architektury 60+ podejmują ważną problematykę dotyczącą równych szans poszczególnych grup wiekowych w uczestniczeniu w życiu społecznym i dostępie do właściwych warunków życia i usług. Forma działalności fundacji oraz zbudowanie interdyscyplinarnego zespołu jest między innymi efektem potrzeby dynamicznej współpracy pomiędzy środowiskiem nauki a sektorem biznesu w komercjalizacji badań naukowych. 


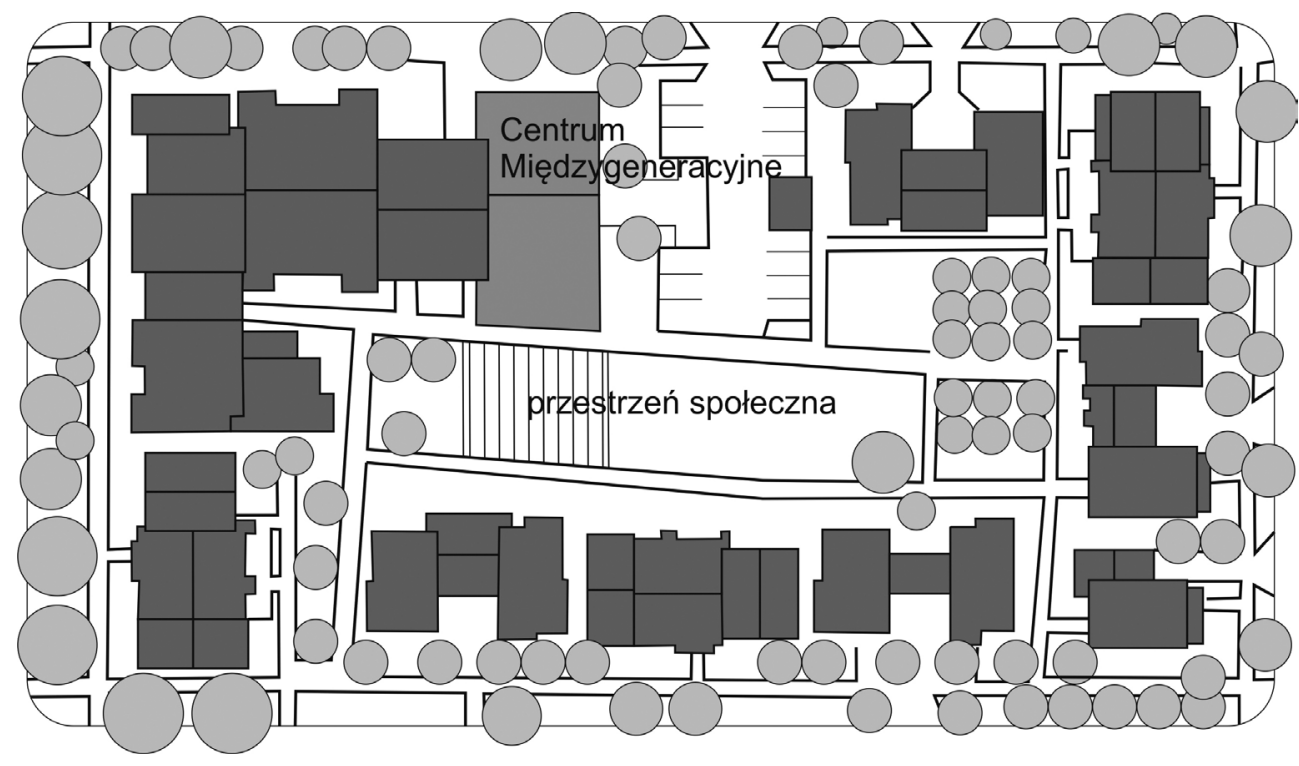

II. 1. Plan osiedla Bridge Meadows w Portland z wewnętrznym dziedzińcem (źródło: opracowanie własne na podst. www.exteriorsdesign.com/grid-portfolio/bridge-meadows)

III. 1. Plan of the Bridge Meadows housing estate, Portland with internal courtyard
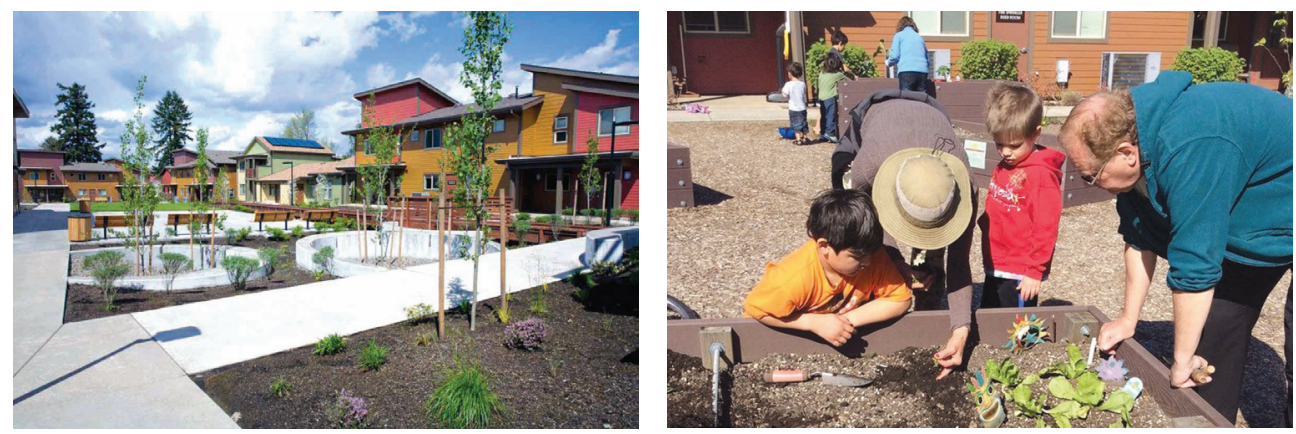

II. 2a, 2b. Przestrzeń społeczna osiedla Bridge Meadows wzmacniająca interakcje mieszkańców (źródło: www.exteriorsdesign.com/grid-portfolio/bridge-meadows)

III. 2a, 2b. The social space of the Bridge Meadows housing estate fostering the inhabitants's interactions 

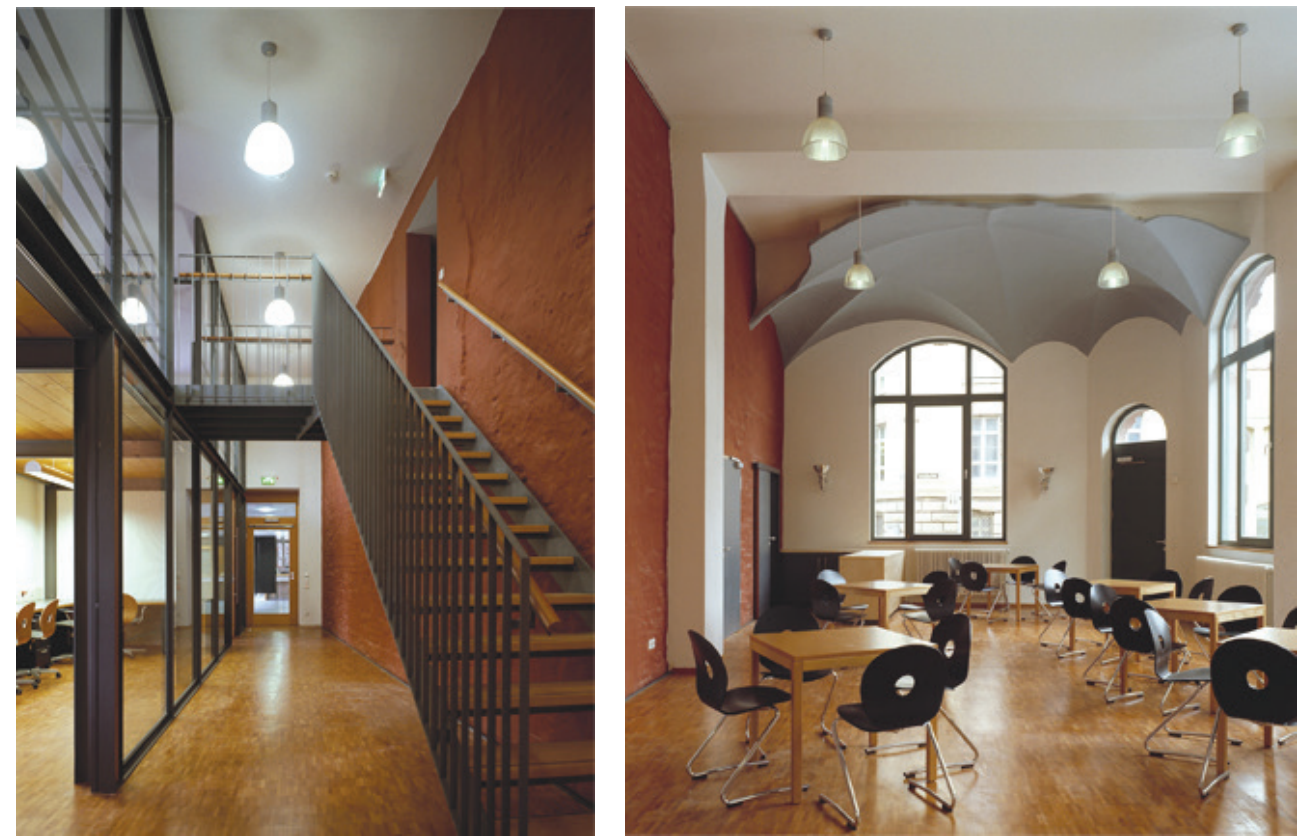

II. 3a. Dom międzypokoleniowy Heslach w Stuttgarcie, widok strefy wejściowej oraz jednej z sal klubowych (źródło: drei-architekten.de/de/alle_projekte.html?projekt=28)

III. 3a. Intergenerational house Heslach in Stuttgart, view of the entrance area and one of the club room

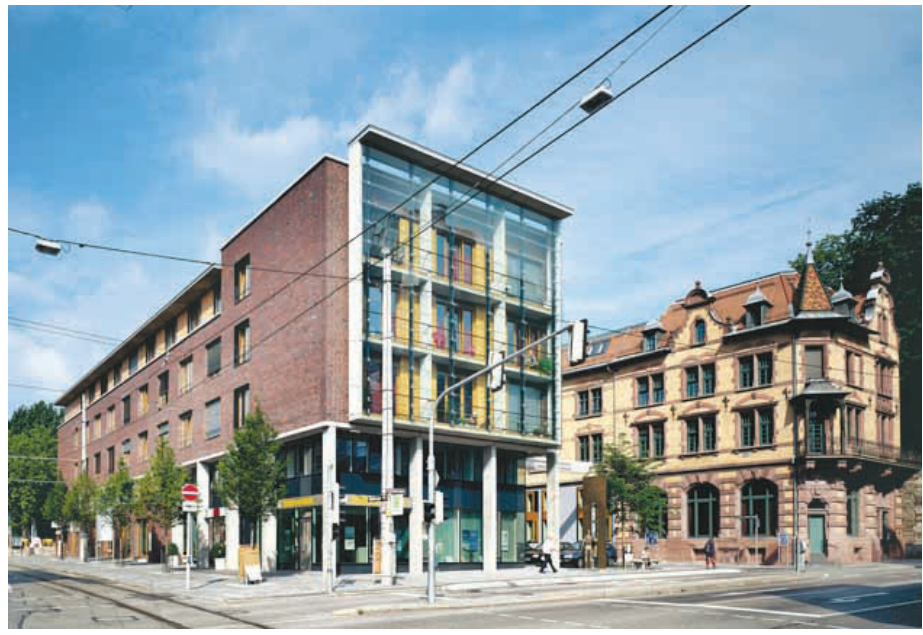

II. 3b. Dom międzypokoleniowy Heslach w Stuttgarcie, widok budynku w kontekście urbanistycznym (źródło: drei-architekten.de/de/alle_projekte.html?projekt=28) III. 3b. Intergenerational house Heslach in Stuttgart, view of the building in urban context 


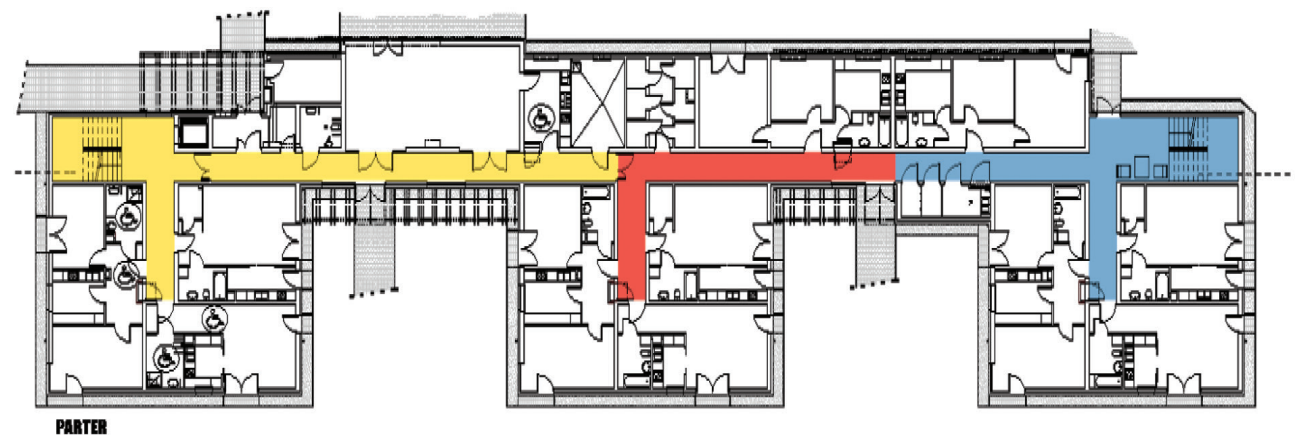

II. 4. Rzut przyziemia zrealizowanego segmentu osiedla dla osób starszych w Stargardzie Szczecińskim (źródło: archiwum własne, fot. A. Labus)

III. 4. Ground floor plan of realized segment of housing estate for the elderly in Stargard Sczeciński
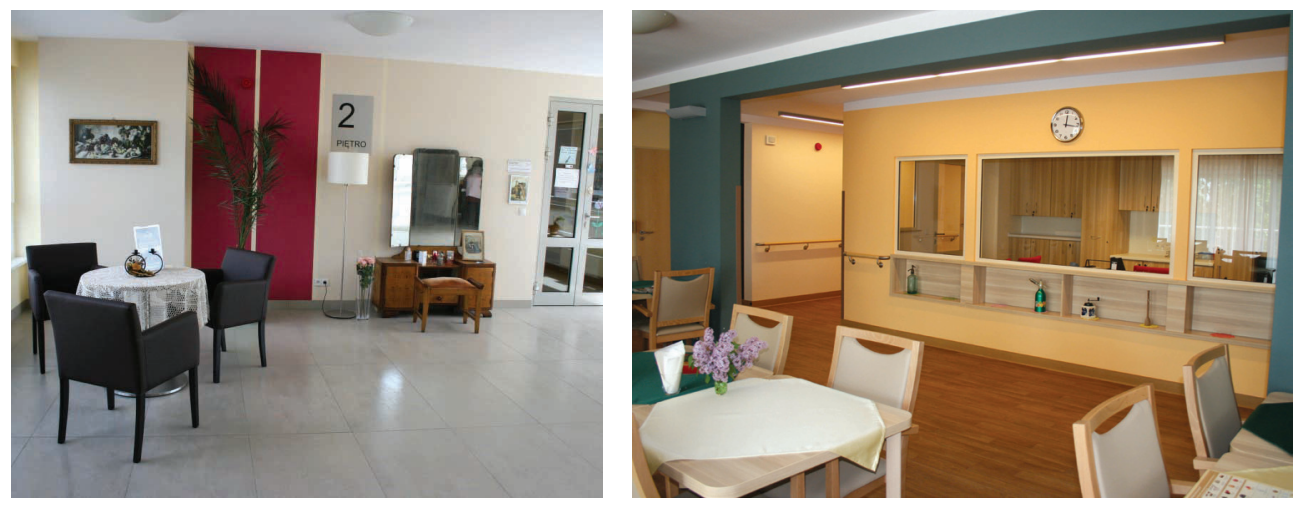

II. 5. Senior Residence na osiedlu Bażantowo, Katowice: a) Widok przestrzeni wspólnych: strefa komunikacji z miejscami wypoczynku (fot. A. Szewczenko), b) Widok jadalni połączonej ze strefą personelu (fot. A. Szewczenko)

III. 5. Senior Residence, Bażantowo housing estate, Katowice: a) View of the common space: circulation area with the resting places, b) View of the dining room connected with the staff area 


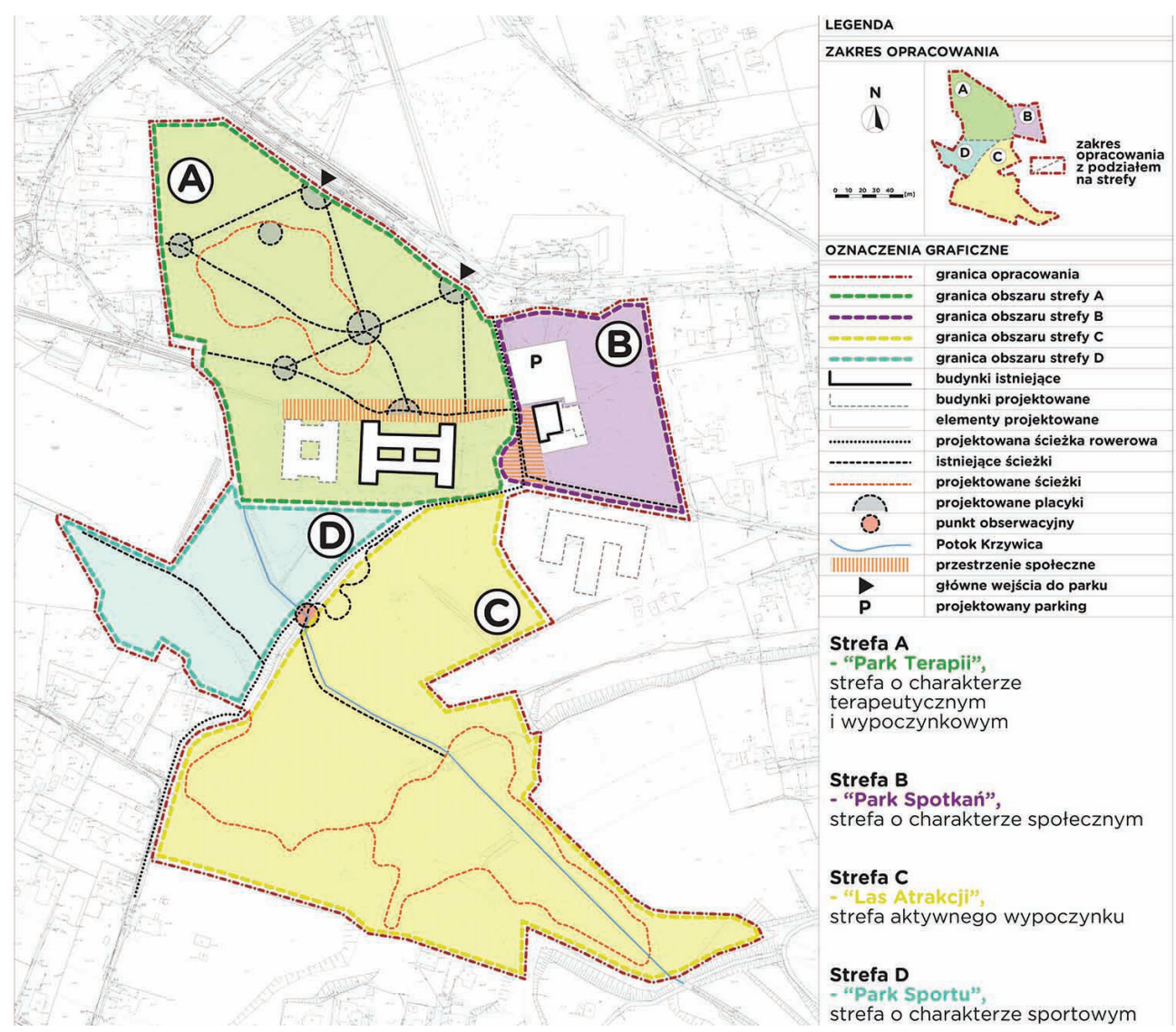

II. 6. Strefy funkcjonalne w „Parku z perspektywą 60+” (opis w tekście). Autorzy: zespół w składzie A. Labus, A. Szewczenko, M. Kampka (LAB 60+) (źródło: archiwum LAB 60+)

III. 6. Functional areas in "Park with the perspective of 60+" (description in the text). Authors: A. Labus, A. Szewczenko, M. Kampka (LAB 60+) 

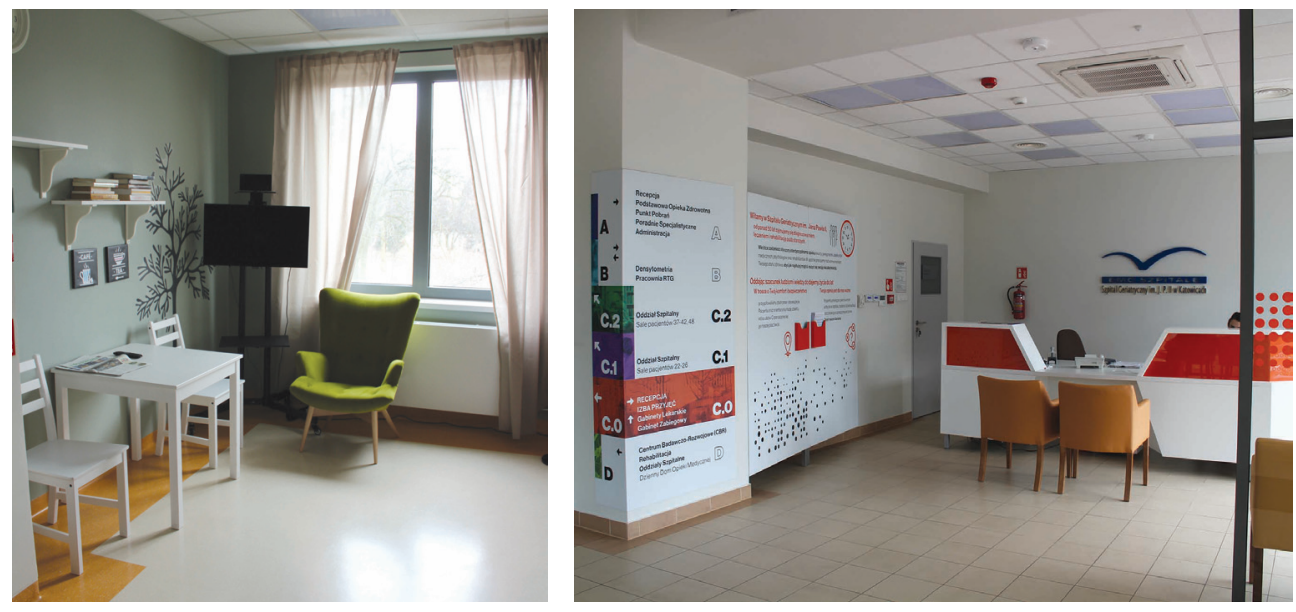

II. 7. Widoki wnętrz w Szpitalu Geriatrycznym w Katowicach, budynek C: a) Kącik dla pacjenta w strefie wejściowej na oddział, b) Recepcja z punktem informacyjnym (fot. A. Szewczenko)

III. 7. View of the interiors of the geriatric hospital in Katowice, building C: a) Patient's area in the entrance of the ward, b) Information desk 


\section{PRZYPISY}

1 M. Rudnicka, A. Surdej, Gospodarka senioralna. Nowy sektor gospodarki narodowej w Polsce, Krajowy Instytut Gospodarki Senioralnej, 2013 (dostęp: 20.02.2015).

2 K. Zimnoch, Starzenie się i srebrna gospodarka w uwarunkowaniach rozwojowych Podlasia, Optiumum. Studia Ekonomiczne, nr 4 (64), 2013, s. 25-36.

3 P. Błędowski, B. Szatur-Jaworska, Z. Szewda-Lewandowska, P. Kubicki, Raport na temat sytuacji osób starszych w Polsce, Instytut Pracy i Praw Socjalnych, Warszawa 2012; Pojęcie „polityki antywykluczeniowej” wprowadzone zostało przez R. Szarfenberga. Natomiast A. Zubrzycka-Czarnecka pojęcie to definiuje jako „działania i programy podejmowane przez instytucje publiczne we współpracy z organizacjami społecznymi i sektorem prywatnym na rzecz integracji społecznej i inkluzji ludzi starszych, mieszkających w miastach oraz promowania solidarności międzypokoleniowej”. Wg A. Zubrzycka-Czarnecka, Polityka miejska wobec starzenia się populacji miast - na przykładzie Polski, Francji i Kanady, „Problemy Polityki Społecznej. Studia i Dyskusje", Nr 18/2012, s. 119-128.

4 Miasta przyjazne starzeniu: przewodnik, Fundacja Res Publica im. Henryka Krzeczkowskiego, Warszawa 2014.

5 M. Zrałek, Zaspokojenie potrzeb mieszkaniowych osób starszych. Dylematy i kierunki zmian, [w:] O sytuacji ludzi starszych, J. Hrynkiewicz (red.), Rządowa Rada Ludnościowa, Warszawa 2012.

6 HAPPI Housing our Ageing Population, Panel for Innovation. Homes and Communities Agency, London 2009.

7 Modele tworzenia inkluzywnych społeczności zamieszkujqcych budynek mieszkalny, w szczególności uwzględniajqce osoby starsze i niepełnosprawne, A. Labus, M. Kampka, M. Pawlus (red.), LAB 60+, Gliwice 2016.

8 W domu działalność prowadzi także centrum Gebrüder Schmidt, inicjujące działania na rzecz dialogu międzypokoleniowego i międzykulturowego.

9 A. Labus, Domy międzypokoleniowe odpowiedziq na starzenie się społeczeństwa w XXI wieku, „Acta Universitatis Lodziensis Folia Oeconomica”, 4 (315) 2015, s. 71-90.

10 Memorabilia to przedmioty codziennego użytku lub ważne pamiątki, które są istotne np. dla osoby starszej z punktu widzenia łączących się z nimi pozytywnych skojarzeń ze zdarzeniami lub ludźmi. Wykorzystywane są głównie do terapii dla osób chorych na zespoły otępienne, gdyż odwołują się do trwałego zapisu w pamięci chorego. 


\section{BIBLIOGRAFIA}

Błędowski P., Szatur-Jaworska B., Szewda-Lewandowska Z., Kubicki P., Raport na temat sytuacji osób starszych w Polsce, Instytut Pracy i Praw Socjalnych, Warszawa 2012.

Labus A., Domy międzypokoleniowe odpowiedziq na starzenie się społeczeństwa w XXI wieku, „Acta Universitatis Lodziensis Folia Oeconomica”, 4 (315), 2015, s. 71-90.

HAPPI Housing our Ageing Population, Panel for Innovation. Homes and Communities Agency, London 2009.

Miasta przyjazne starzeniu: przewodnik, Fundacja Res Publica im. Henryka Krzeczkowskiego, Warszawa 2014.

Modele tworzenia inkluzywnych społeczności zamieszkujących budynek mieszkalny, w szczególności uwzględniajqce osoby starsze i niepełnosprawne, A. Labus, M. Kampka, M. Pawlus (red.), LAB 60+, Gliwice 2016.

Rudnicka M., Surdej A., Gospodarka senioralna. Nowy sektor gospodarki narodowej w Polsce, Krajowy Instytut Gospodarki Senioralnej, 2013 (dostęp: 20.02.2015).

Zimnoch K., Starzenie się i srebrna gospodarka w uwarunkowaniach rozwojowych Podlasia, Optiumum. Studia Ekonomiczne, nr 4 (64), 2013, s. 25-36.

Zrałek M., Zaspokojenie potrzeb mieszkaniowych osób starszych. Dylematy i kierunki zmian, [w:] O sytuacji ludzi starszych, J. Hrynkiewicz (red.), Rządowa Rada Ludnościowa, Warszawa 2012.

Zubrzycka-Czarnecka A., Polityka miejska wobec starzenia się populacji miast-na przykładzie Polski, Francji i Kanady, „Problemy Polityki Społecznej. Studia i Dyskusje”, Nr 18/2012, s. $119-128$.

www.exteriorsdesign.com/grid-portfolio/bridge-meadows (dostęp: 20.02.2015). 